Arab World English Journal (AWEJ) Volume 12. Number1 March 2021

DOI: https://dx.doi.org/10.24093/awej/vol12no1.20

\title{
English Language Pronunciation Barriers Encountered by the Expatriate Students at King Saud University, Riyadh
}

\section{Kesavan Vadakalur Elumalai}

Department of English Language and Literature, Faculty of English, College of Arts, King Saud University

Riyadh, Kingdom of Saudi Arabia

Correspondent Author: ekesavan@ksu.edu.sa

\section{Mohammad Sufian Abdullah}

Department of English Language and Literature

College of Arts, King Saud University,

Riyadh, Kingdom of Saudi Arabia

\section{Jayendira P Sankar}

College of Administrative and Financial Sciences

AMA International University, Kingdom of Bahrain

\section{Kalaichelvi R}

College of Administrative and Financial Sciences

AMA International University, Kingdom of Bahrain

Received: 11/20/2020

Accepted: 2/3/2021

Published: $3 / 24 / 2021$

\section{Abstract}

The English language pronunciation is a sub-skill of speaking modules during the learning process of a second language. Accurate pronunciation is not followed enough by Bangladesh students in speaking English It was found that the participants face barriers while pronouncing English. However, it is ignored and even provided the least attention by them. In order to explore the pronunciation barriers of vowels and consonants of Bangladesh expatriate learners and to identify remedial measures, this study stresses about four aspects of pronunciation: vowel confusion and insertion, missing stress sounds, sounds' errors cause of written form, and absence of fricatives. The study emphasizes on the value and status of pronunciation and overcame the approach of it among Bangladesh expatriate students. A pronunciation test was conducted with 8 Bangladesh expatriate learners with an age range of 20-25 years and the participants were asked to pronounce 7-8 words in every aspect, recorded their voice and documented for analysis along with observation of the Bangladesh expatriate learners at King Saud University. The study reveals that Bangladeshi students have many errors on the way to the correct vocalization of English sounds, which are mainly the influence of their mother tongue. Bangladeshi Learners could not make the distinction between long and short vowels. To overcome this problem, learners need to participate pronunciation practice in the formal assessment process in addition to language lessons and also focus their attention on conversation through multimedia.

Keywords: absence of fricatives, Bangladesh expatriate students, higher educational level, missing stress sounds, recorded voice, sounds' errors cause written form, vowel confusion and insertion.

Cite as: Kesavan, V.E., Mohammad, S. A., Jayendira, P. S., \& Kalaichelvi, R. (2021) English Language

Pronunciation Barriers Encountered by the Expatriate Students at King Saud University, Riyadh. Arab World English Journal, 12 (1) . DOI: https://dx.doi.org/10.24093/awej/vol12no1.20 


\section{Introduction}

In Bangladesh, Bangla is the official language in all aspects of life and places such as schools, markets, parks, and streets. Like many other countries, the English language in Bangladesh is the second language. Teacher and learners in Bangladesh are often ignorant about pronunciation. Non-native speakers make slips or faults when they use English. Ellis (2003) In Bangladesh, English, as a first global lingua franca, first world language, and language of commerce, science, and technology, is dominating higher education, trades, corporate offices, mass entertainment, courts, and media for many years. There English is considered as a superpower to bring social status and modernize a man. People feel proud and smart for speaking in English. Influential elite groups, decision-makers speak in English. Hence learning English is essential for Bangladeshi people. As a second language, Bangladeshi students learn English from the primary label of education. For the differentiation of the articulator system and pronunciation between Bangla and English, the Bangladeshi students face many difficulties in learning English. Most of them face difficulties in pronunciation. Pronunciation is the primary key to communication with people. Without correct pronunciation, it is not easy to communicate with native people Also, lousy pronunciation may lead to misunderstanding in communication, although the speakers have good grammatical and reading skills.

Consequently, learning pronunciation is essential to English learners. Kelly (2001) states that including teaching pronunciation in the classrooms is essential because learners' errors may guide to misunderstanding and prevent fruitful communication. Incidentally, what is the pronunciation? Robinett (1985) says that it is "the act or the result of producing the sounds of speech, including articulation, vowel formation, accent, inflection, and intonation. They often concern the correctness or acceptability of the speech sounds" (64). Consonant and vowels are assumed to be the basis of pronunciation.

Bangla has 11 vowels and 39 consonant letters. "English alphabet contains 26 letters of Latin script" Hopkins (2017) in which five vowels and 21 consonants. Though Bengali has more vowels and consonants, some English sounds have no equivalent in Bangla. For example, /3/ and /z/ sounds. Another reason why English is difficult for SLL that, for 26 letters in English, it has 39 sounds. One sound has a few phonemes. For example, the letter "a" can be pronounced like [o] as in "law" and [a:] like in "father" and [ə] in "ago" and [æ] in "pat" and [er] in "make." Another cause is, the English language has many accents, Irish, Welsh, Scottish, and mainly British and American accents. Every accent has a different pronunciation. Sometimes British and American use different words to describe a thing, which leads the English language learners in difficulties for acquisition.

English is written in the Latin alphabet, whereas Bangla script is derived from the eastern variety of Brahmi, the Latin alphabet and Brahmi are different languages from each other, whether in writing or speaking. English has two forms for the alphabet. Small and capital forms. However, in the Bangla language, all letters have only one form. In Bangla, there is no need to capital the first letter of the sentence and the first letter of some specific words, which may guide Bangladeshi learners to more difficulties in learning English. 
The study focuses on English pronunciation barriers among Bangladeshi students and analysis what kind of errors being produced by them in the higher class. The researcher will also provide some remedies to the students and teachers to overcome the barriers and errors. This study will find out the problems and errors encountered by Bangladeshi students in the pronunciation of English sounds and also will discover the barriers to correct pronunciation and how students would overcome these errors. Thus, this study may find a solution to fill the gap between the barriers and correct pronunciation. The researcher chooses eight students for conducting the research. All the students are adults. Their ages are from 22s to 30s. All students have finished secondary school level, and they are studying a bachelor's degree in different faculties at King Saud University in Riyadh. The researcher uses an android mobile phone to record students' voices (pronunciation).

\section{Literature Review}

Pronunciation errors are a common phenomenon in many countries where English is a second language or foreign language. The learner identifies the fault and he/she can answer it by himself/herself. Gilakjani (2011) Rivers (1981) has argued that language is an important way of communication. Learning grammatical rules, vocabularies, and phrases are not sufficient for students until they are not able to pronounce the language, which he wants to learn, in a way that the native speakers of that language can understand their expression correctly. Jenkins (2011), non-native speakers impossible to pronounce as the native speaker; rather non-native speakers can try to learn the pronunciation which is mutually agreed to native and non-native speakers. She emphasized some phonemes that a non-native speaker must learn and some phonemes are not as important as others are. (Jenkins, 2011, p. 9)

Second language learners also face barriers from their mother language. Robinett (1985) told that learners' first language or mother tongue plays a great rule to interfere in gaining the skill of expression in a foreign language. For example, at the beginning stage of learning the English language, Spanish native people more commonly pronounce thank $(/ \theta æ j \mathrm{k} /$ as sank (/sæyk/) and thing (/Oin/) as sing (/sin/). The reason why Spanish people pronounce like that is Spanish has no equal sound of $/ \theta /$ as has in English. Therefore, Spanish people replace the primary sound of the thing, which is $/ \theta /$ sound, with /s/ sound, which is nearly similar to the/ $\theta /$ sound.

Wahba (1998) examines the difficulties encountered by Egyptian students in learning English as a second language. He finds out that some specific phonological errors made by Egyptian students are related to stress and intonation. She also describes the reason for errors, which are the different phonological features of English and Arabic. Ahmad (2011) found that Arab students scarcely can pronounce certain consonant sounds in the right way. For instance, the voiceless bilabial plosive /p/ sound has no equivalent in the Arabic language; hence Saudi students cannot easily understand the voiceless of $/ \mathrm{p} /$ sound. Instead, they replace the sound with a voiced /b/ sound. Begum and Hoque (2016) stated that, in some specific situations, some English sounds disappear in some words. The tertiary level students of Bangladesh encounter this problem. They do not pronounce a single sound while uttering a word. For example: they vocalize /skrıpts/ as /skrıps/, /ækts/ as /æks/, without phoneme "t". They also do not utter stress sound perfectly. Like; (Iinteresting) /'Intrəstıy/ as /Interəstıy/, (tourist)/'tu:rist/ as /tu:rist/ without 
stress in the initial of the words and (literature) /'litritforr/ as /lı' tarifforr/ with stress in wrong position.

According to Ramelan (1994), there are some pronunciation problems faced by Indonesian students when they want to learn English as a foreign language. They are a) move of Linguistic habit, b) different components between mother language and second language, c) the similarity of phonetic features in both languages but the difference in their distributions, d) same sounds in both languages, but these sounds have different variations or allophones, and e) Similar sounds in two languages, but those sounds differ slightly in their phonetic features. Native people of Arabic, Japanese, Korean, Tagalog, and other essential dialects of all present Iberian Romance Languages have difficulties in differentiation [b] and [v] sounds, what is called betacism (Hopkins, 2017).Hassan (2000) said that Arab students find difficulties in the vocalization of some specific words due to the difference and discrepancy in the orthography and pronunciation of those words. For example, the/f/ sound it could be represented by the letter $\mathbf{f}$ or the combination of ph in phantom, and gh in a laugh. Here it is evident that there is no similarity between letters and sound, which makes English spelling and pronunciation more problematic to learn and teach for Arab students and teachers.

\section{Methodology}

The present study examines eight Bangladeshi students at King Saud University. They are all adults. They have never been in any country where English is the first language. They are divided into two groups: the first group is the students of science and engineering faculty at Kings Saud University, where English is the means of teaching, and the second group is the students of art faculty at KSU, in which English is not the medium of teaching. English department students are not included in the research's subjects. This study stresses about four aspects of pronunciation. Which are: vowel confusion an insertion, missing stress sounds, sounds' errors cause of written form, and absence of fricatives: The researcher met the participants each week until eight weeks to test and collect the data. The subjects are told about the research so they can be aware of their pronunciation and other activities. They are asked to pronounce 7-8 words in every approach, and recorded their pronunciation in android mobile. They are allowed to prepare for reading around five to ten minutes before they start. Every week the obtained data is analyzed by the researcher himself and other specialists in English pronunciation. The researcher also uses Oxford Learner's Dictionaries to compare the participants' sounds and the sounds in the dictionary. Only 8 learners from two colleges were considered due to study limitations. The Science and Engineering and College of Arts were selected purposively and then the learners were selected randomly. (SeeTable1.) The pronunciation test was designed on phonemes of English.

\section{Results}

\section{Vowel Confusion and Insertion}

In group one, most of the students are confused in the monophthong $/ \mathrm{s}$ sound in small and soar. They pronounced /a/, / /, / $/ \mathrm{a} / \mathrm{l} / \mathrm{u} /$ sounds instead of $/ \mathrm{s} /$ sound. One student pronounced the $/ \mathrm{s} /$ properly. Two students were confused in the /e/ sound; instead, they pronounced the/I/ sound in bet. However, surprisingly they all pronounced the same sound /e/ correctly in the net. Most of the students pronounced the/u/ sound correctly in the zoo. Only one student mispronounced;

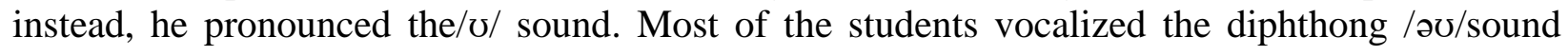


wrongly in-joke and hole. They pronounced /u/, / , / / / sounds instead of the /əv/ sound. Only one student pronounced correctly. Finally, two students added /I/ and /e/ sounds before /s/ sound in small.

Table 1. Gives the information about the vowel confusion and insertion errors in the group one

\begin{tabular}{|c|c|c|c|}
\hline word & $\begin{array}{c}\text { correct pronunciation by } \\
\text { objects. }\end{array}$ & $\begin{array}{l}\text { wrong pronunciation by } \\
\text { objects }\end{array}$ & notes \\
\hline Small & /smo:1/ 1 & /smal/ 3 & $\begin{array}{l}\text { Adding /e/ and /I/ sounds } \\
\text { before /s/ sound. }\end{array}$ \\
\hline Soar & /so:r/ 1 & /sor/ 1, /svar/ 1, /sur/ 1 & \\
\hline Hide & /hard/ 4 & & \\
\hline Net & /net/ 4 & & \\
\hline Zoo & /zu:/ 3 & $/ \mathrm{d} z \sigma / 1$ & $\begin{array}{l}\text { Pronounced /z/ sound as } \\
\text { /dz/ sound by } 1 \text { student. }\end{array}$ \\
\hline Joke & /dzəok/ & /dzok/ 3, /dzuk/ 1 & \\
\hline Hole & /həol/ 1 & /hol/ 2, /hol/ 1 & \\
\hline Bet & /bet/ 2 & /bit/ 2 & \\
\hline
\end{tabular}

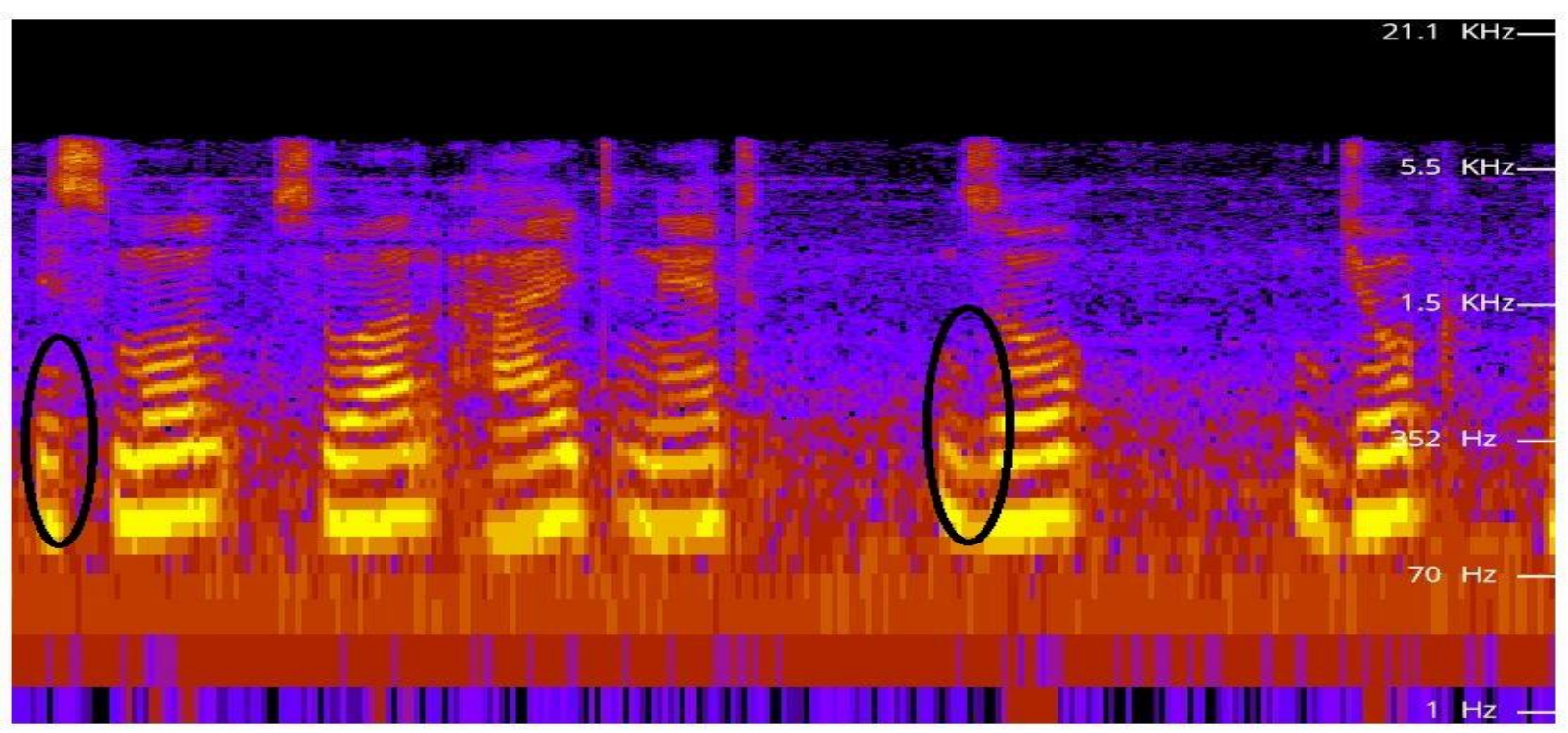

Figure 1. Shows the vowel confusion and insertion errors in group one 
In a group, two more students had similar confusion problems with vowel sounds to the students of group one. Also, some different errors appeared in the pronunciation vowel sounds. Like, one student pronounces the / / sound instead of the $/ \mathrm{\rho} /$ sound in soar. Two students pronounced the $/ \mathrm{p} /$ sound in the place of /ov/ sound in soar. There is also adding /I/ vowel mistake before the /s/ sound in small. All of the participants pronounced correctly /ai/ sound in hiding and the /e/ sound in the net. Table two illustrates the errors that occurred by the students in vowel sounds and how many students pronounced correctly.

Table 2. Demonstrates the vowel confusion and insertion errors in group 2

\begin{tabular}{|c|c|c|c|}
\hline word & $\begin{array}{l}\text { correct pronunciation by } \\
\text { objects. }\end{array}$ & $\begin{array}{l}\text { wrong pronunciation by } \\
\text { objects }\end{array}$ & notes \\
\hline Small & /smo:1/ 3 & $/ \mathrm{smal} / 1$ & Adding /I/ sounds before /s/ sound. \\
\hline Soar & /so:r/ & /suar/ 3, /suər/ 1 & \\
\hline Hide & /hard/ 4 & & \\
\hline Net & /net/ 4 & & \\
\hline Zoo & /zu:/ 4 & & $\begin{array}{l}\text { Pronounced /z/ sound as /dz/ sound by } \\
1 \text { student. }\end{array}$ \\
\hline Joke & /dzəok/ 1 & /dzok/ 1, /dzuk/ 2 & $\begin{array}{l}\text { Pronounced /z/ sound in the /dz/ } \\
\text { sound by one student }\end{array}$ \\
\hline Hole & /həol/ 1 & /hol/ 1, /hpl/ 2 & \\
\hline Bet & /bet/ 3 & $/ \mathrm{bIt} / 1$ & \\
\hline
\end{tabular}

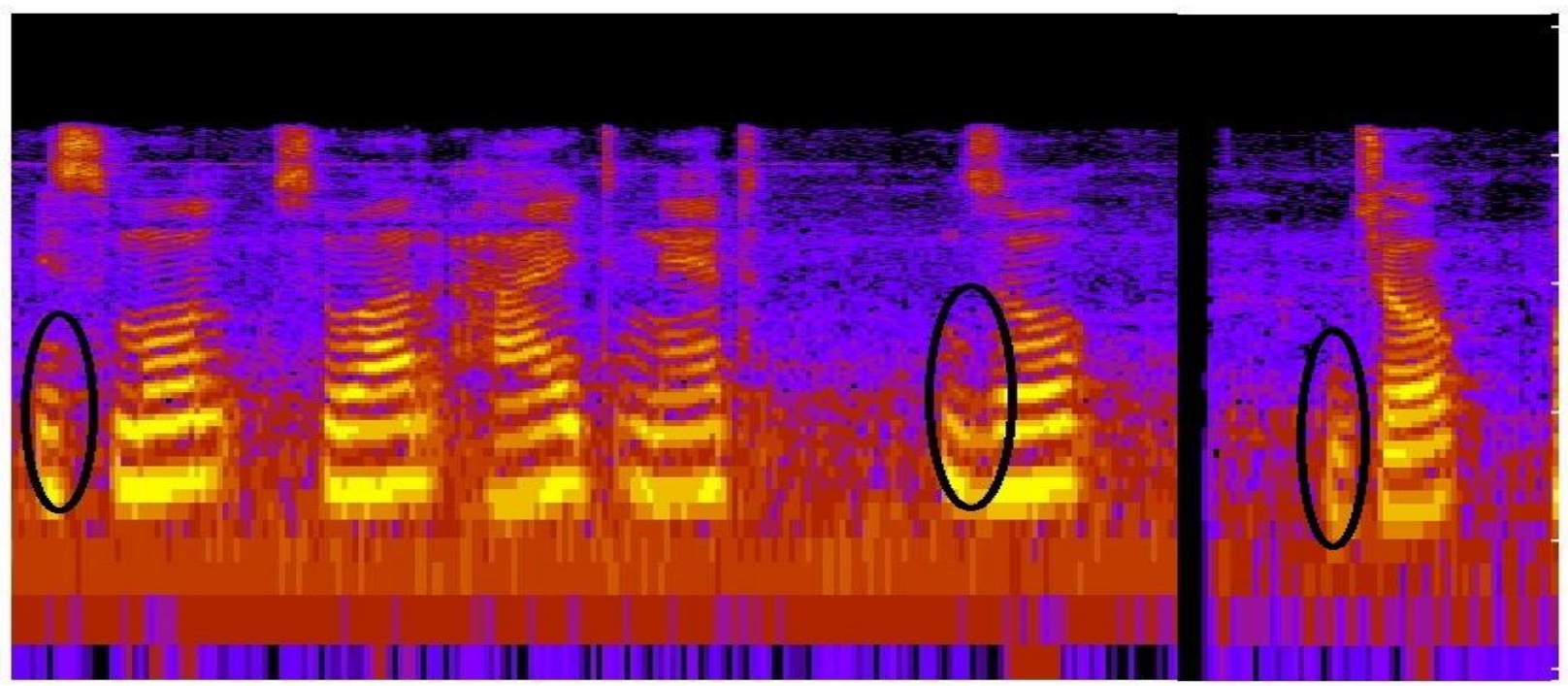

Figure 2. Shows the vowel confusion and insertion errors in group two 


\section{Missing stress}

It is another problem that can be encountered by EL is missing stress in words or sentences. Some stress in words is meaningful. They differentiate nouns from verbs. For example, "overflow" if we stress on the first syllable as "overflow' it will be a noun, and stress on the last syllable as "over' flow" makes its verb. We can produce a stressed syllable by pushing more air from our lungs. Thus, a stressful syllable or word increases respiratory activity. It may also raise laryngeal activity (Ladefoged and Johnson, 2014). Stressed syllables are more prominent than unstressed syllables. According to Roach (2001), here are some factors which make a stressed syllable prominent. They are loudness, length, pitch, and quality. It does not need all these four factors to make a syllable stressed; instead, only one or two factors can make a syllable stressed.

Ladefoged and Johnson (2014) stated that stress has few functions in the English language. They are a) for emphasizing a word or contradicting one word to another, stress can be used in the English language. b) for indicating the syntactical variation of parts of speech and c) in illustrating the grammatical structures of the words.

In group one, without considering any other pronunciation mistake, most of the students missed the stress on the right syllable in words such as record, open envy, and equal. Only one student stressed correctly in open and equal. Most of the students could not differentiate nouns from verbs in words such as subject and insult. They failed to make the stress in the second syllable while subject and insult are verbs and at the beginning of those words while they are nouns. Only one student stressed correctly in subject and insult as nouns. Table four shows the number of students who missed the stress and who stressed the words correctly.

Table 3. Depicts the stress errors in the group one

\begin{tabular}{|c|c|c|c|}
\hline word & correct stress & miss stress & notes \\
\hline Subject & /səb'dzekt/ 0 & /səbdzekt/ 4 & As a verb \\
\hline Subject & /'s 1 bdzekt/ 1 & /sıbdzekt/ 3 & As a noun \\
\hline Insult & /In's sılt/ 0 & /Ins $\Lambda$ lt/ 4 & As a verb \\
\hline Insult & /'Insslt/ 1 & /Ins 1 lt/ 3 & As a noun \\
\hline Record & /'reko:d/ 0 & /reko:d/ 4 & \\
\hline Open & /'əэрәn/ 1 & /əupən/ 3 & \\
\hline Envy & /'envi/ 0 & /envi/ 4 & \\
\hline Equal & /'i:kwəl/ 1 & /i:kwəl/ 3 & \\
\hline
\end{tabular}




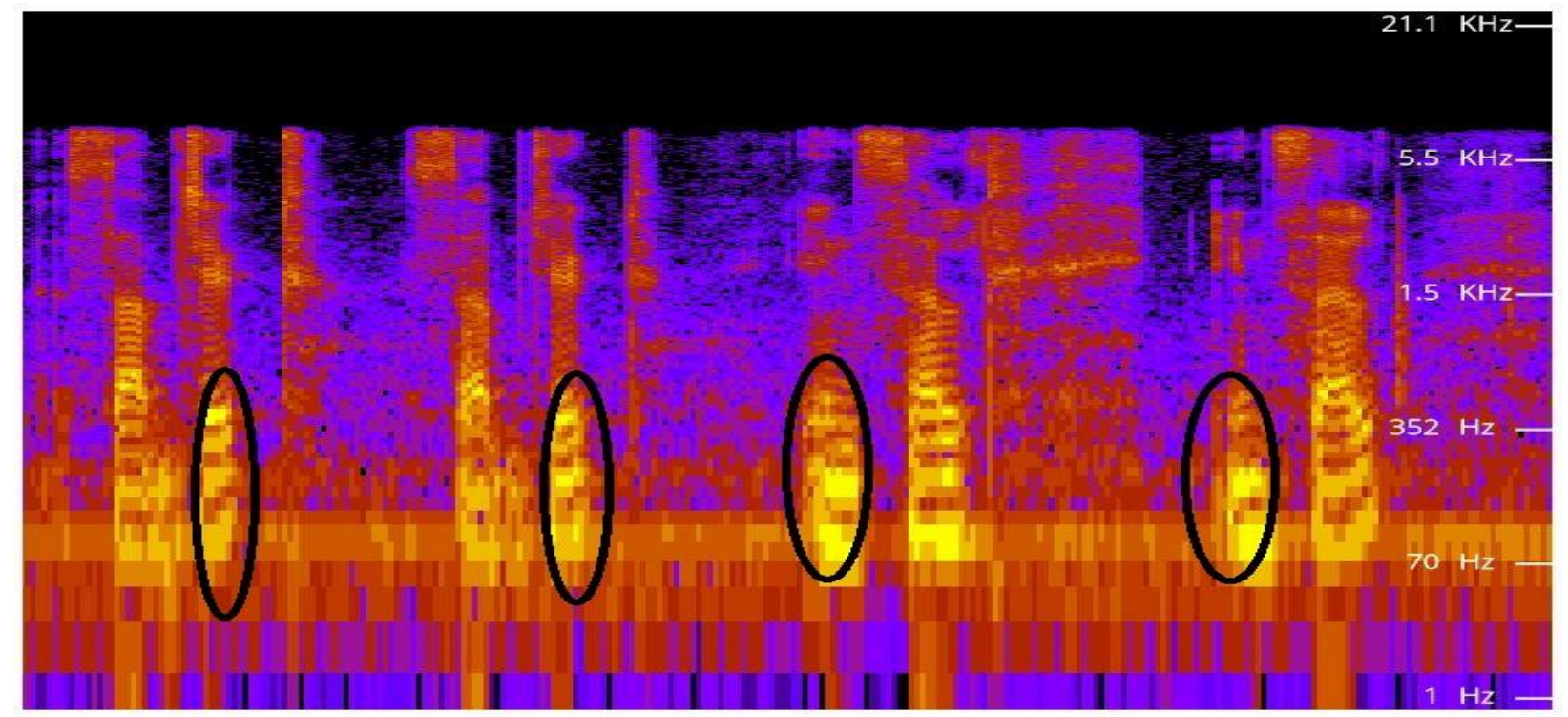

Figure 3. Illustrates the stress errors in the group one

In group two, as same as group one, most of the students missed the stress in words such as record, open, envy, and equal. Only two students correctly stressed the word equal. Only one student stressed correctly in the word subject as a noun, and all other students failed to make stress correctly in words subject and insult whether they are nouns or verbs. Table 4 shows the number of students who stress correctly or wrongly.

\begin{tabular}{|c|c|c|c|}
\hline words & correct stress & miss stress & notes \\
\hline Subject & /səb'dzekt/ 0 & /səbdzekt/ 4 & As a verb \\
\hline Subject & /'s $\Lambda$ bdzekt/ 1 & /sıbdzekt/ 3 & As a noun \\
\hline Insult & /In's s lt/ 0 & /Ins $\Lambda$ lt/ 4 & As a verb \\
\hline Insult & /'Ins $\Lambda$ lt/ 1 & /Ins $\Lambda 1 t / 3$ & As a noun \\
\hline Record & /'reko:d/ 0 & /reko:d/ 4 & \\
\hline Open & /'әupən/ 0 & /əupən/ 4 & \\
\hline Envy & /'envi/ 0 & /envi/ 4 & \\
\hline Equal & /'i:kwəl/ 2 & /i:kwəl/ 2 & \\
\hline
\end{tabular}




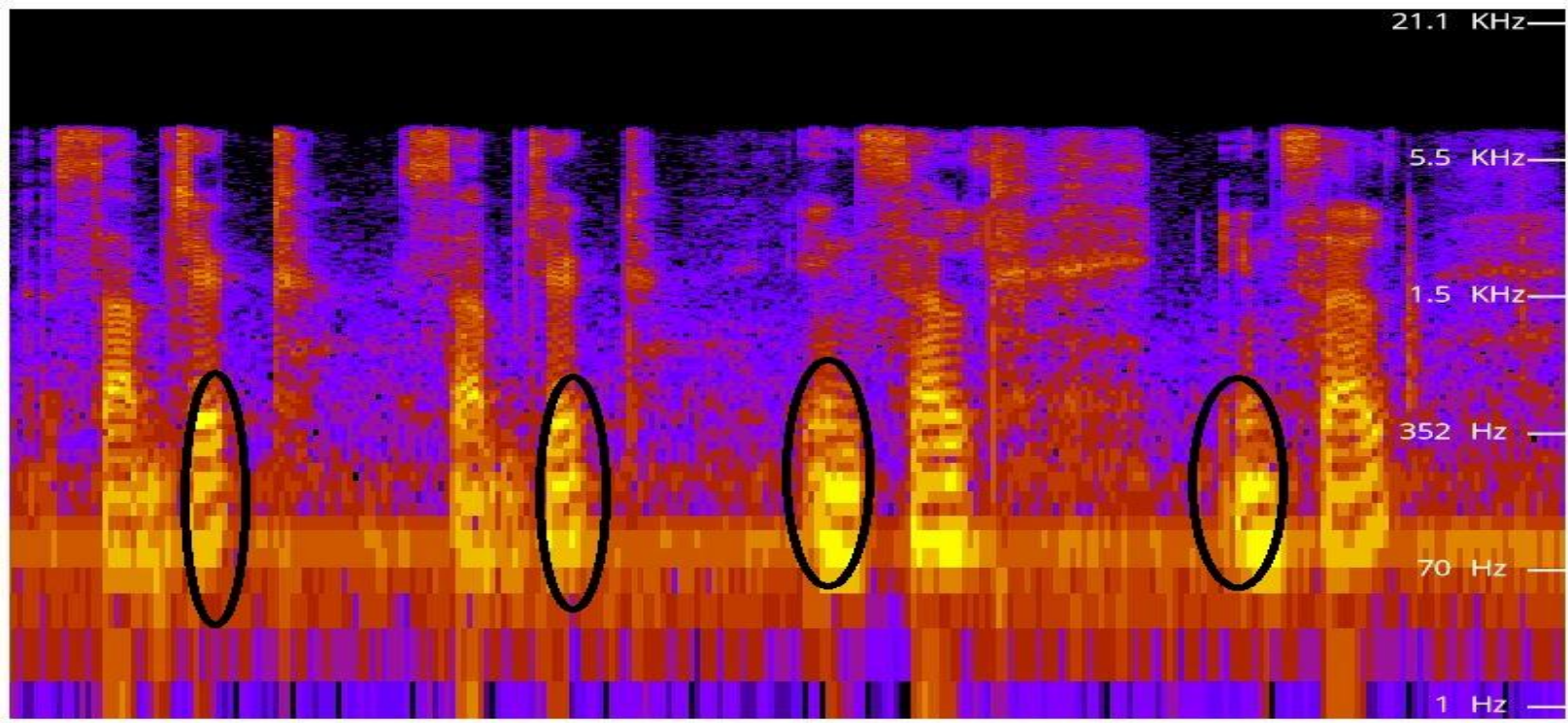

Figure 4. Shows the stress errors in the group two

\section{Written Form}

Bangladeshi students face pronunciation problems because of the written form. They are confused by silent words. In group one, all students pronounce the $/ \mathrm{s}$ sound correctly in thought and slaughter. Two students mispronounce silent/a/sound in incidentally. They pronounce /, Insi'dentali/ with /a/sound instead of /, Insi'dentli/ without a sound. However, other students pronounce correctly. All students mispronounced the word hasten. They pronounced /a:sten/, /a:sn/, /psten/, /a Jn/ sounds instead of '/eIsn/ sound. Most of the students pronounced the word sigh correctly. Only one student pronounced wrongly /ai/ sound in a sigh . He added /t/ sound with /ai/ sound. Most of the students pronounced the proper surgeon. However, one student confused with silent sound /o/. He pronounced/'dzeon/. Half of the students pronounced /o:Sra:s/ and /ov $\int \mathrm{n} /$ in the place of $/ \mathrm{\rho}: \int \mathrm{s} /$, while other students were right in their pronunciation. Table five shows the error sounds created by the students because of the written form of the words.

Table 5. Shows the written form of errors in the group one

words correct pronunciation wrong pronunciation

\begin{tabular}{|c|c|c|}
\hline Incidentally & /, Insi'dentli/ 2 & /, Insi' dentali/ 2. \\
\hline Thought & $/ \theta$ o:t/ 4 & None \\
\hline Slaughter & /'slo:tə(r)/ 4 & None \\
\hline Hasten & /'heisn/ 0 & /ha:sten/ 1, /ha:sn/ 1, /hpsten/ 1, /hafn/ 1. \\
\hline Sigh & /sai/ 3 & /sait/ 1 \\
\hline Surgeon & /'s3:dzən/ 3 & /'s3:dzeon/ 1 \\
\hline Cautious & 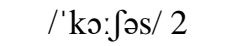 & 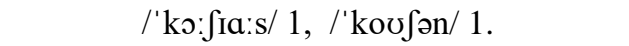 \\
\hline
\end{tabular}




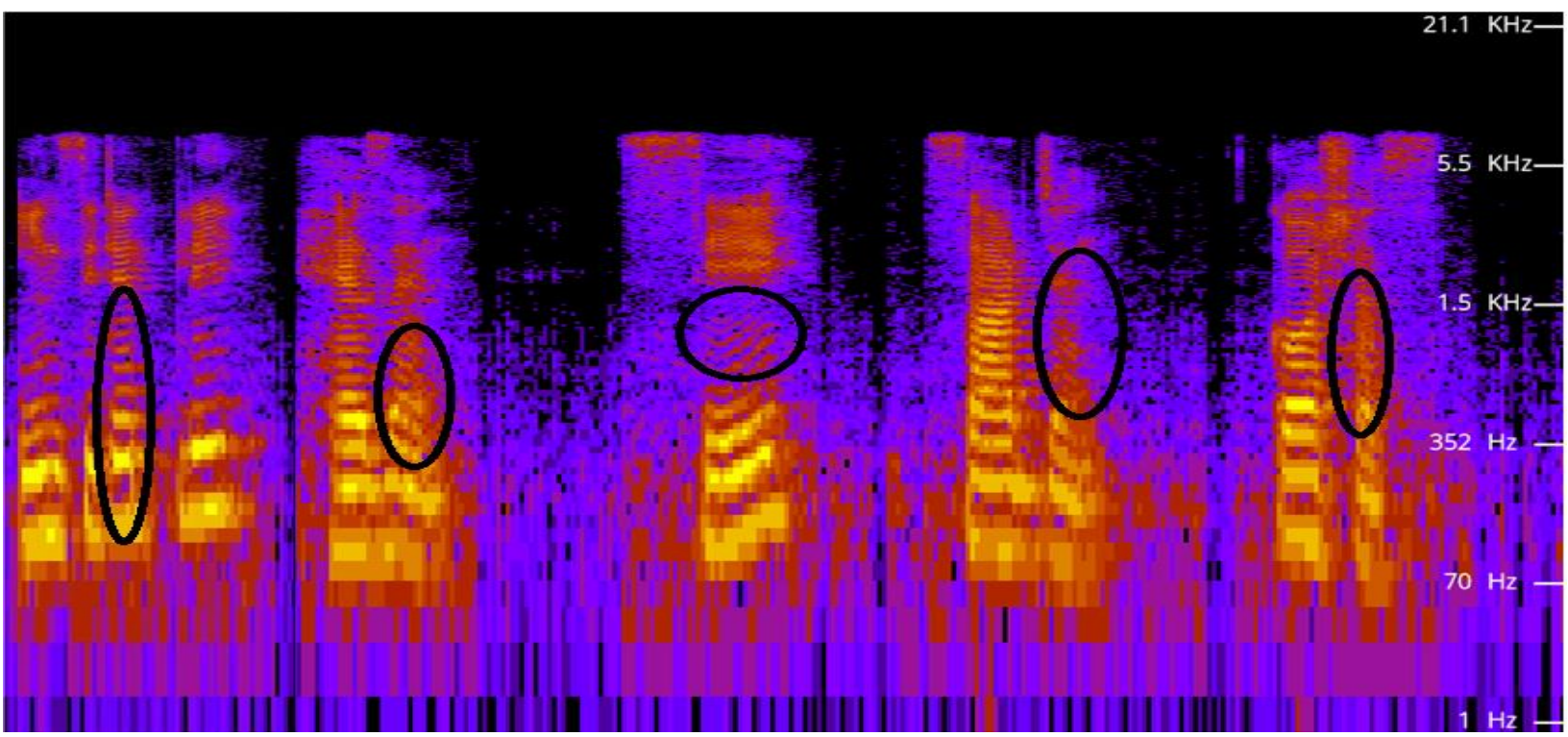

Figure 5. Describes the written form of errors in the group one

In group two, most students pronounced correctly, though, and slaughter, like group one. Only one student pronounced the/ð/ sound instead of the /t/ sound in slaughter. All students pronounced exactly the word incidentally. All students mispronounced hasten as like as group 1. They pronounced /esten/, /a:sten/, and /ezen/ in the place of /eIsn/. All students could not pronounce the surgeon correctly. They replaced /dzon/ sound by /zıon/, /zən/, /zen/, and /dzen/ sounds. One student vocalized the ai sound in a sigh, and one cannot read the word, and two students pronounced /ain/ and /i/ sounds instead of the ai/ sound. The word cautious is confused by one student as he pronounced $/ \mathrm{fn} / \mathrm{instead}$ of $/ \int 2 \mathrm{~s} /$, while two students vocalized correctly, and one student could not vocalize. Table 6 illustrates the number of students in group 2, pronounced correctly, and the students who could not in the written form problems.

Table 6. Shows written form problems in the group two

\begin{tabular}{lll}
\hline words & correct & notes \\
& pronunciation & wrong pronunciation
\end{tabular}

\begin{tabular}{|c|c|c|c|}
\hline Incidentally & /,Insi'dentli/ 4 & None & \\
\hline Thought & $/ \theta$ s:t/ 4 & None & \\
\hline Slaughter & /'slo:tə(r)/ 3 & /'slo:ðə(r)/ 1 & \\
\hline Hasten & /'heisn/ 0 & /hesten/ 2, /ha:sten/ 1, /hezen/ 1. & \\
\hline Sigh & /sai/ 1 & /sain/ 1, /si/ 1 & No pronunciation 1. \\
\hline Surgeon & /'s3:dzən/ 0 & /s3:zıon/1, /s3:zən/ 1, /s3:zen/1, /s3:dzen/ 1. & \\
\hline Cautious & 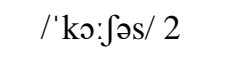 & /'ko:fn/ 1 & No pronunciation 1 \\
\hline
\end{tabular}




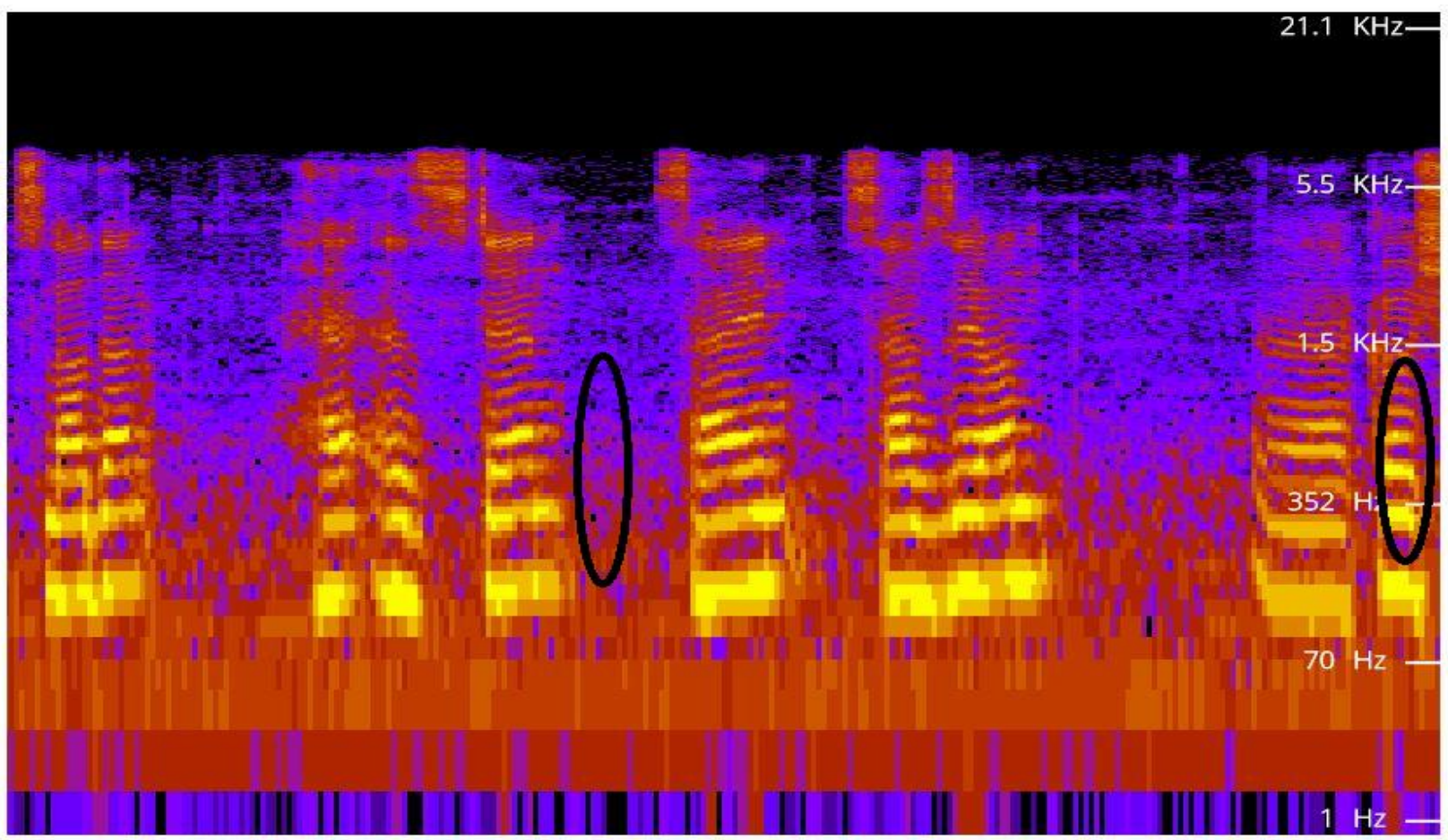

Figure 6. Shows written form problems in group two

\section{Fricatives}

To produce fricative consonant sounds, two articulators come close together and make a narrow passage so that the air goes through this with producing intense hissing noise. Therefore, fricatives like plosives and affricates, distinguished by voice elements. Sometimes this hissing noise or friction associated with voice or not (Gimson, 1989). According to Ward (1972), there are ten fricative consonants in English. They are f, v; $\theta$, ð; s, z; $\int, 3 ; \mathrm{x} ; \mathrm{h}$.

In group one, all students mispronounced fricative labiodental sounds /f/, /v/, and dental $/ ð /$ in the words father, vote, and there. Most of the students pronounced correctly / $/$ / sound in the shop. Only one student failed to vocalize the fricative $/ \mathrm{J} / \mathrm{sound}$ in the word. The glottal fricative sound $/ \mathrm{h} /$ in hot is pronounced correctly by half of the students and also mispronounced by the same students. Most of the students could not pronounce correctly alveolar fricative /s/ sound in site while only one student did. All students correctly pronounced dental fricative $/ \theta /$ sound in thank. Table seven demonstrates the number of students who correctly pronounced fricative sounds and who did not.

Table 7. Shows fricative problems in the group one

\begin{tabular}{cccc}
\hline Words & With fricative & Without fricative & Notes \\
\hline Father & $/$ 'fa:ðə(r)/ & /'fa:ðə(r)/4 & \\
Vote & /vəut/ 0 & /vəut/ 4 & While 3 students pronounced /bhut/ \\
Thank & $/ \theta æ \eta \mathrm{k} / 4$ & $/ \theta æ \eta \mathrm{k} /$ none &
\end{tabular}




\begin{tabular}{ccc}
\hline There & /ðеə(r)/ 0 & /ðеə(r)/ 4 \\
Shop & $/ \mathrm{jpp} / 3$ & $/ \mathrm{jpp} / 1$ \\
Hot & $/ \mathrm{hpt} / 2$ & $/ \mathrm{hpt} / 2$ \\
site & $/ \mathrm{saIt} / 1$ & $/ \mathrm{saIt} / 3$ \\
\hline
\end{tabular}

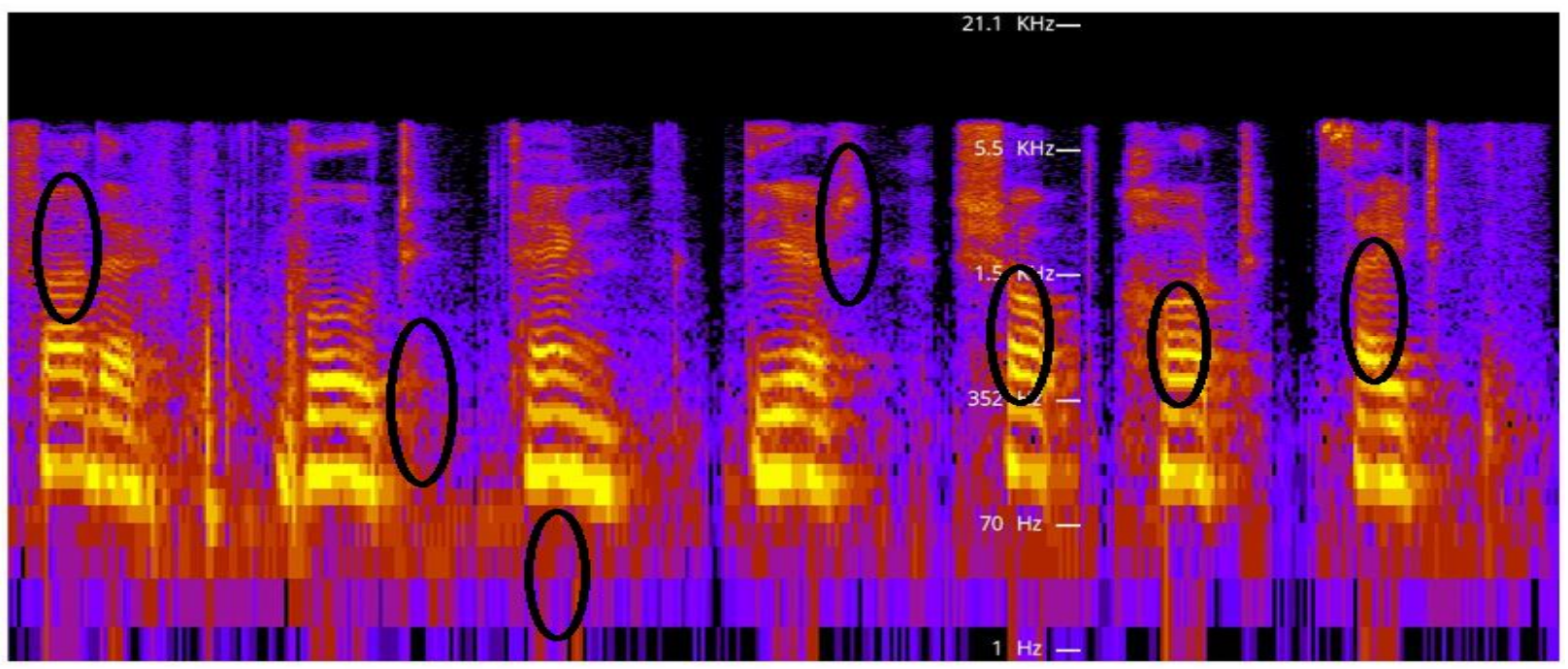

Figure 7. Shows fricative problems in the group one

In group two, all students pronounced correctly $/ \theta /$ sound in thank as like as group one. Half of the students vocalized exactly fricative sounds $/ \mathrm{f} /, / \mathrm{J} /, / \mathrm{h} /$ and $/ \mathrm{s} /$ in words father, shop, hot, and site, and another half of the students mispronounced those fricative sounds. Most of the students vocalized wrongly labiodental fricative /v/ sound and dental fricative /ð/ sound in the vote and there, and only one student did correctly. Table eight gives information about how many students pronounced fricative sounds correct and how many mispronounced.

Table 8.Shows fricative errors in the group two

\begin{tabular}{|c|c|c|c|}
\hline words & with fricative & without fricative & notes \\
\hline Father & /'fa:ðə(r)/ 2 & /'fa:ðə(r)/ 2 & \\
\hline Vote & /vaut/ 1 & /vaut/ 3 & While 2 students pronounced /bhut/ \\
\hline Thank & $/ \theta æ \eta \mathrm{k} / 4$ & $/ \theta æ \eta \mathrm{k} / 0$ & \\
\hline There & /ðеə(r)/ 1 & /ðеə(r)/ 3 & \\
\hline Shop & $/ \int \mathrm{pp} / 2$ & $/ \int \mathrm{pp} / 2$ & \\
\hline Hot & /hpt/ 2 & $/ \mathrm{hpt} / 2$ & \\
\hline Site & /sait/ 2 & /sait/ 2 & \\
\hline
\end{tabular}




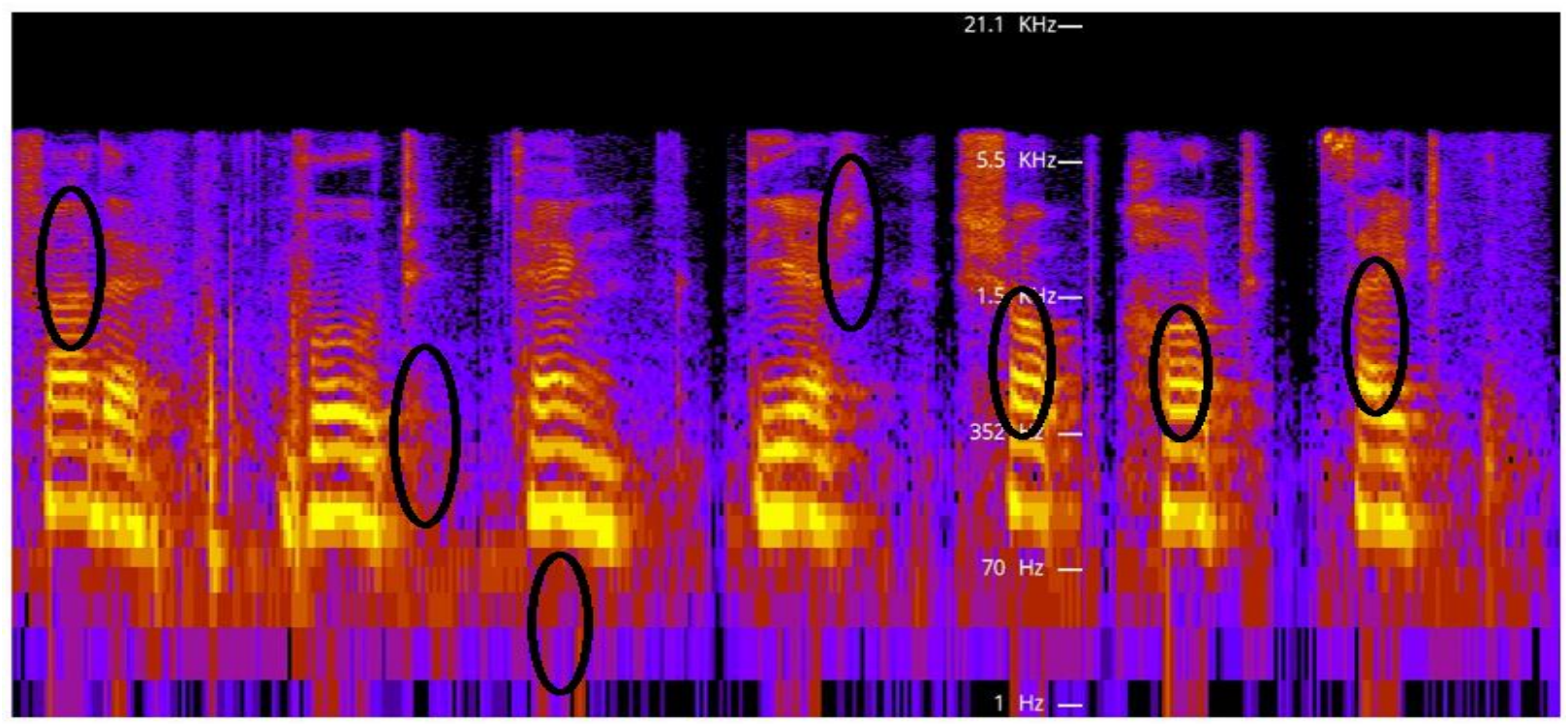

Figure 8. Shows fricative errors in group two

\section{Summary of the Findings}

According to Roach (1998), there are 25 vowels in English phonetics (short-7, long5, dipthongs-8, tripthongs-5). Both group one and group two students are the same in making pronunciation errors. English, as a means of the educational system, does not affect pronunciation. The summary of results is described as.

This study concentrated on vowel confusion an insertion, missing stress sounds, sounds' errors cause of written form, and absence of fricatives only, and found the following problems: Learners cannot make the distinction between long and short vowels of English. Problems in vowel confusion and insertion: a) changing vowel sound / / / with / /,/, /va/, /a/, /uə/ and /u/

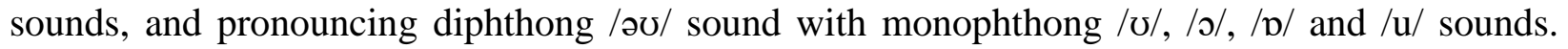
Missing stress: missing stress is common among Bangladeshi students. According to Roach (2001), there are 24 consonants in English phonetics. According to Huq (1990), five consonants are absent (four completely and one /r/ partially) in the Bangla phonetics. Written form: a) /eisn/ sound in hasten turns into /a:sten/, /a:sn/, /psten/, /a fn/, /esten/, and /ezen/ sounds, and /dzon/ sound in surgeon/ pronounced as zıon/, /zən/, /zen/, /dzen/ and /dzeon/ sounds. Fricatives: /f/, /v/, $/ ð /, \mathrm{h} /$ and /s/ sounds vocalized without fricative sounds.

\section{Recommendations}

Bangladeshi educational and social environment is not appropriate to learn correct pronunciation. Most People cannot understand correct pronunciation, whether British or American dialect. Even sometimes, people laugh at the person who speaks in the British or American dialect. People use their dialect in speaking English, which is far beyond the correct English pronunciation. Students need to be very enthusiastic and careful about correct pronunciation. The researcher suggests some rules to cope with pronunciation errors. They are,

1. The first step in the correction of L2 pronunciation is, as Wijk (1966) said, to learn the vocalization of each new word, separately, encountered by learners when they begin to 
learn the language, either from a teacher or any kind of phonetic transcription ignoring many references of any rules of the pronunciation of the letters with which the words are made up.

2. Students should focus on the manner of articulation of English letters.

3. They should follow the natives' pronunciation.

4. They may follow any authentic online program where teaches correct English pronunciation.

5. Teachers should correct students' pronunciation in the classes and encourage them to speak in the correct dialect.

6. Students should emphasize speaking correctly from the primary level of education.

7. Institutes can play a significant role in developing correct pronunciation by proposing more pronunciation courses for teachers and students.

8. There are many websites and online English dictionaries which provide exact pronunciation for English words, students can follow them. Such as, "Oxford Learner's Dictionaries" and "Cambridge Dictionary" has both British and American dialect for English words.

9. Students can also use technology software like rosetta and pronunciation coach to score their vowels' and consonants' production through what is called the language intelligibility scorer. Hence, this may also help them in writing their pronunciation awareness.

10.

\section{Conclusion}

The importance of the English language is flourishing day by day in Bangladesh as well as in the world. Nowadays, no one can deny the worth of the English language as it is the language of science, technology, trade, and global communication. For appropriate communication with people, the correct pronunciation is vital for everyone. A pronunciation test was conducted with 8 Bangladesh expatriate learners and the participants were asked to pronounce 7-8 words in every aspect, documented for analysis along with observation of the Bangladesh expatriate learners at King Saud University. The study reveals that Bangladeshi students have many errors on the way to the correct vocalization of English sounds, which are mainly influence of their mother tongue. Bangladeshi Learners could not make the distinction between long and short vowels. To overcome this problem, learners need to participate pronunciation practice in the formal assessment process in addition to language lessons, and also focus their attention on conversation through multimedia, the researcher believes the study may help to improve pronunciation errors to those who follow it.

\section{About the Authors:}

Kesavan Vadakalur Elumalai, Ph.D. is an associate professor of Applied Linguistics in the department of English Language and Literature, College of Arts at King Saud University, Riyadh, Saudi Arabia. He has published a few articles in the field of language teaching and learning in reputed journals and he is one of member in a research group approved by Deanship of Scientific Research at King Saud University. https://orcid.org/0000-0001-5700-3294. (Correspondence author)

Mohammad Sufian Abdullah: a graduate student in the Department of English Language and Literature of King Saud University, Riyadh, Saudi Arabia. He is interested on English linguistics 
especially language acquisition and English pronunciation. He holds a diploma degree on Arabic language from Arabic Linguistic Institute of King Saud University as well. https://orcid.org/0000-0001-7047-9588

Jayendira P.Sanka, PhD is an assistant professor of MBA at AMA International University in the Kingdom of Bahrain. He has fourteen years of academic experience and fellow HEA-UK with over fifty publications in various international journals. The current research interests include, quality of e-learning in higher education, blended learning, employee development, and employee satisfaction. drpjai14@gmail.com, https://orcid.org/0000-0001-8435-2123.

R. Kalaichelvi, PhD, is an Assistant Professor at AMA International University in the Kingdom of Bahrain. She received the Best Paper award at the IEEE conference in 2017 and served as a reviewer for SmartTech-2017 and the International Journal of Information Technology and Web Engineering. Her research focuses on Cloud Computing, Employee Development \& Satisfaction, E-learning, and Blended Learning in Higher Education. kalai_hasan@yahoo.com, https://orcid.org/0000-0002-8355-7669.

\section{References}

Ahmad, J. (2011). Pronunciation Problems among Saudi Learners: A Case Study at the Preparatory Year Program, Najran University Saudi Arabia. Language in India, 11(7), 22-36.

Begum, A., \& Hoque, M. A. (2016). English Pronunciation Problems of the Tertiary Level Students in Bangladesh: A Case Study. Researchers World: Journal of Arts, Science \& Commerce, 7(4), 50-61.

Ellis, R. (2003). Second Language Acuisition. Oxford University Press, New York.

Gilakjani, A.P. (2011). A Study on the Situation of Pronunciation Instruction in ESL/EFL Classrooms. Journal of Studies in Education. 1(1), E4. Macrothink Institute. Iran.

Gimson, A. C. (1989). An Introduction to the Pronunciation of English (4 ${ }^{\text {th }}$ ed.). Hodder Arnold.

Hassan, Z. M. (2000). English Phonetics \& Phonology for Arab students (2 ${ }^{\text {nd }}$ ed.). Amman: Dar Al-Hamed.

Hopkins, S. (2017). English Language and Learning. Larsen and Keller Education.

Huq, M. D. (1990). Teaching English Pronunciation to Bangla L2 Learners. Journal of The Institute of Modern Languages. 2(2).

Jenkins, J. (2011). Global English and Teaching of Pronunciation, Teaching English. British Council. BBC. Retrieved from http://goo.gl/1QTWpH

Kelly, G. (2000). How to teach pronunciation. In How to ( $1^{\text {st }}$ ed.). Persons Education Limited Ladefoged, P., \& Johnson, K. (2014). A Course in Phonetics $\left(7^{\text {th }}\right.$ ed.). Cengage Learning.

Ramelan, M. A. (1994). English Phonetics. Upt Unnes Press.

Rivers, W. M. (1981). Teaching Foreign Language Skills ( $2^{\text {nd }}$ ed.). University of Chicago Press.

Roach, P. (2001). English Phonetics and Phonology: A Practical Course (3 ${ }^{\text {rd }}$ ed.). Cambridge: Cambridge University Press. 
Roach, P. (1998). English Phonetics and Phonology. Cambridge: Cambridge University Press, UK.

Roach, P. (2001). Phonetics. Oxford University Press, New York.

Robinett, B. W. (1985). Teaching English to Speakers of Other Language: Substance and Technique. University of Minnesota Press.

Wahba, E. H. (1998). Teaching pronunciation-why? Language Teaching Forum, 36(3), 3-32.

Ward, I. C. (1972). Phonetics of English (5 ${ }^{\text {th }}$ ed.). W. Heffer \& Sons Ltd.

Wijk, A. (1966). Rules of Pronunciation for the English Language. Oxford: Oxford University Press. 